\title{
Continuidade, Ruptura ou Reciclagem? Uma Análise do Programa Político do Banco Mundial após o Consenso de Washington*
}

\author{
João Márcio Mendes Pereira
}

Universidade Federal Rural do Rio de Janeiro (UFRRJ). Rio de Janeiro, RJ, Brasil. E-mail: joao_marcio1917@yahoo.com.br

O Banco e seus funcionários não deverão intervir em assuntos políticos de nenhum membro; nem tampouco deverão ser influenciados em suas decisões pelo caráter

político do membro ou dos membros interessados. Somente considerações econômicas deverão ser relevantes para suas decisões, e essas considerações serão ponderadas imparcialmente (Banco Mundial, Artigos de Fundação, 1944).

O líder eficiente dá ao público o senso de que a reforma pertence ao povo e não foi imposta de fora para dentro. A reforma do Estado requer a cooperação de todos os grupos da sociedade. A compensação dos grupos por ela afetados (que podem nem sempre ser os mais pobres) pode ajudar a garantir o seu apoio. Embora possa sair caro a curto prazo, a compensação valerá a pena a longo prazo (Banco Mundial, 1997:15).

O terror chegou à nossa porta. (...) É absolutamente certo que juntos combateremos o terror. É nossa obrigação. No entanto, o perigo está em que, ao nos preocuparmos com as ameaças imediatas, percamos a perspectiva de mais longo prazo e das causas igualmente urgentes do nosso mundo inseguro: a pobreza, a frustração e a falta de esperança. (...) Se quisermos estabilidade em nosso planeta, precisamos lutar para acabar com a pobreza

(Wolfensohn, 2004:2).

\footnotetext{
* Pesquisa financiada pelo Conselho Nacional de Desenvolvimento Científico e Tecnológico (CNPq) e pela Fundação Carlos Chagas Filho de Amparo à Pesquisa do Estado do Rio de Janeiro (Faperj).
}

DADOS - Revista de Ciências Sociais, Rio de Janeiro, vol. 58, no-2, 2015, pp. 461 a 498. 
E ste artigo tem como objetivo discutir o programa político do Banco Mundial (BM) entre os anos de 1989 e 2012. Para isso, além do diálogo com a literatura especializada, o estudo toma como fontes a documentação do próprio BM, como relatórios sobre o desenvolvimento mundial e documentos setoriais e de políticas mais relevantes. Essa documentação traz a mensagem central da entidade sobre temas de importância estratégica.

O estudo não se propõe a analisar as formas por meio das quais o programa político do BM foi implementado por diferentes Estados, o que demanda pesquisas empíricas específicas. Ainda assim, em termos teórico-metodológicos, é importante ressaltar que a relação do BM com os governos nacionais e subnacionais não deve ser vista como mera imposição externa. Embora existam formas e mecanismos de pressão diferenciados (financeiros, políticos, intelectuais e simbólicos) acionados pelo BM conforme as circunstâncias, a atuação da entidade historicamente se deu em meio a uma densa e crescente rede de relações que envolve agentes nacionais e internacionais públicos, privados, não governamentais, filantrópicos e empresariais, os quais, com meios e níveis de gravitação distintos, apoiam, propõem, adaptam, negociam e veiculam as ideias e prescrições da Instituição. Nessa interação, com frequência o discurso e as práticas do BM aportaram argumentos e recursos para dirimir conflitos entre atores concorrentes e consolidar posições de poder e convicções ideológicas próprias. Dessa perspectiva, a eficácia das ações do BM necessita da construção de visões de mundo e interesses mútuos e continua sendo dependente de pontos de sustentação, negociação e difusão, tanto dentro como fora dos espaços nacionais ${ }^{1}$.

A hipótese discutida é a de que o programa da entidade sofreu um processo de reciclagem ao longo do período, modelado por fatores externos e internos. Tal reciclagem manteve a centralidade da privatização e da liberalização econômica, mas ampliou a incidência do programa para novas áreas, abarcando gradativamente o conjunto da economia, a relação sociedade-natureza, o Estado, a sociedade civil e a esfera individual, em clave liberal, nos países clientes. O BM é abordado a partir da sua condição singular de emprestador, formulador e articulador de políticas e veiculador de ideias sobre o que fazer em matéria de desenvolvimento capitalista, em clave anglo-saxônica.

O texto está dividido em cinco partes. Inicialmente, discute o período de 1989 a 1995, durante o qual a entidade construiu as bases da sua 
atuação nos anos seguintes. Na segunda parte, aborda a agenda de reformas de segunda geração, centradas no aclamado "retorno do Estado". Depois, analisa as circunstâncias do lançamento do Pós-Consenso de Washington, bem como o teor das medidas preconizadas. Na sequência, problematiza o Marco Integral de Desenvolvimento, lançado em 1999, tomando-o como síntese da politização e do alargamento do mandato do BM. Após, discute as novidades trazidas na década de 2000, que mesclaram o Pós-CW à agenda de segurança internacional impulsionada pelos EUA. Por fim, uma breve conclusão.

\section{DO CONSENSO DE WASHINGTON À CRISE MEXICANA}

Com os governos de Margaret Thatcher e de Ronald Reagan, o ambiente político mundial sofreu uma guinada liberal-neoconservadora brusca e consistente, expressa, entre outras dimensões, na pressão exercida pelo eixo anglo-americano pela liberalização das economias nacionais. No caso da América Latina, essa pressão seria reforçada após a eclosão da crise da dívida externa em 1982. Era o ponto culminante de um processo de endividamento, sobretudo com bancos privados americanos, praticado com a conivência do Fundo Monetário Internacional (FMI) e do BM. A dívida rapidamente se converteu em instrumento para disciplinar em série as políticas econômicas dos países devedores, conforme o credo neoliberal emergente.

A expressão "ajustamento estrutural" se tornou lugar comum nos anos seguintes na maioria dos países da América Latina, da África e em parte da Ásia. O escopo e a abrangência das condicionalidades exigidas pelo BM se ampliaram gradativamente. Entre 1982 e 1985, o objetivo dos programas de ajuste consistia na estabilização macroeconômica de curto prazo, a partir da contenção do consumo interno, do arrocho salarial, do corte de gastos sociais e da redução do investimento público. Depois de 1985, com o Plano Baker, a privatização do setor produtivo estatal entrou na agenda e, logo após, foi a vez da liberalização financeira.

Em 1989, as principais forças que impulsionavam a liberalização realizaram em Washington uma reunião de avaliação de resultados. Registrou-se entre eles o acordo amplo sobre as reformas de política econômica em curso na América Latina, assim como a necessidade de acelerar a sua execução dentro e fora da região. O decálogo de prescri- 
ções ficou conhecido como "Consenso de Washington" (Williamson, 1990).

Erguido sobre os escombros do muro de Berlim, tal decálogo expressava a convergência entre o mainstream do pensamento econômico, o governo republicano dos EUA e os interesses financeiros simbolizados por Wall Street (Guilhot, 2005:197; Babb, 2009 e 2013). Rapidamente, o CW ganhou o status de paradigma único do capitalismo triunfante, servindo para enquadrar os governos dos países da periferia a um programa político centrado na liberalização da economia mundial ao fluxo de bens, serviços e capitais e na reorientação do Estado como provedor de um marco normativo que garantisse a segurança e a lucratividade dos negócios privados (Wade, 1997:353).

Com o objetivo de impulsionar a liberalização econômica, o BM estabeleceu naquela conjuntura quatro coordenadas estratégicas que orientariam a sua ação política, intelectual e financeira nos anos seguintes. Eram elas: a) a difusão de um modelo de política social centrado no aliviamento da pobreza coerente com o ajuste macroeconômico; b) a mudança do papel do Estado na economia; c) a incorporação da questão ambiental no programa político dominante; d) a ampliação do escopo e o manejo das reformas, a partir da entronização da ideia de governança.

Primeiro, a questão do aliviamento da pobreza. Até meados dos anos 1980, o BM afirmara que o ajuste era "bom para os pobres", pois os beneficiaria diretamente, na medida em que o crescimento econômico fosse reativado. Quando ficou claro que não era isso que estava ocorrendo e a pressão política sobre o BM aumentou de todos os lados, o discurso mudou e a instituição começou a admitir a ocorrência de "custos sociais" (Kapur et al., 1997:353; Babb, 2009:161). Isso explica por que, em 1990, a pobreza tenha sido tema do Relatório sobre Desenvolvimento Mundial $\left(\mathrm{RDM}^{2}\right)(\mathrm{BM}, 1990)$. Voltando a enfatizar a relação entre desigualdade internacional, pauperização e instabilidade política - recorrente no discurso da entidade durante a gestão de McNamara (1968-1981) -, o RDM 1990 tinha o objetivo de conciliar e subordinar o aliviamento da pobreza à liberalização econômica radical. Sua premissa básica era a separação entre política social e política econômica. Ancorado na categoria da "pobreza absoluta", o RDM 1990 deixava de lado a questão da concentração de renda e riqueza e propunha uma estratégia dual, que combinava programas focalizados com a confiança 
renovada nas virtudes redentoras do crescimento econômico e do "efeito derrame" - isto é, o gotejamento gradual da renda para os estratos mais baixos da estrutura social. Não por acaso, o conflito em torno da produção e apropriação da riqueza era desconsiderado, o que permitia ao BM propor que o aliviamento da pobreza dependia tão somente da distribuição de parte dos resultados do crescimento econômico, sem envolver a redistribuição do estoque de ativos patrimoniais e financeiros. Em outras palavras, a agenda pro-poor do RDM 1990 afirmava a crença de que o crescimento econômico era a única solução para a pobreza e que somente podia ser alcançado mediante políticas orientadas ao mercado. O BM começava então a sair da pauta macroeconômica estreita da era Reagan e voltar ao tema da pobreza do período McNamara, mas num caminho coerente com o ajuste e funcional à sua expansão (Babb, 2009:165).

A segunda coordenada consistiu na redefinição do papel do Estado na economia. O RDM 1991 prescreveu o enfoque "amigável com o mercado" (market-friendly approach). Segundo Wade (1997), tal operação se devia muito mais ao desafio japonês do que à oposição das esquerdas. A contradição entre as propostas de "livre mercado" e "mercado dirigido" havia emergido no início dos anos 1990, incidindo sobre o debate em torno da (des)regulação dos mercados financeiros. Por trás desse embate estava a disputa entre Japão e EUA (Amsden, 1994:630). No contraponto à pressão globalizadora liderada pelos EUA e veiculada pelo BM, o Japão aumentava sua gravitação política e econômica na Ásia e lutava para que o seu enfoque servisse de modelo para a Rússia no pós-Guerra Fria.

Para o BM, especificamente, o papel do Estado se resumia a apoiar, fortalecer e complementar o mercado em regime de livre concorrência. Ou seja, já não se tratava mais de condenar a "intervenção estatal" na economia como algo indesejável, mas sim de reconhecer o âmbito de ação legítimo do Estado. Qual? O que se "harmoniza" com o mercado e permite a maximização da concorrência. Nesse sentido, a ação estatal deveria estar a serviço dos "mercados", deixando que eles "funcionem por si mesmos, a não ser que se possa demonstrar que é melhor intervir" (BM, 1991:6).

Segundo o RDM 1991, as funções fundamentais do Estado se resumiam a garantir a estabilidade macroeconômica e o ambiente propício à competitividade, manter a ordem pública, investir em "capital hu- 
mano" (educação primária e saúde básica), fornecer infraestrutura produtiva, proteger o meio ambiente, controlar a natalidade e gerir a previdência social. Como agente econômico, o Estado estaria irremediavelmente condenado ao fracasso.

Estabelecidas as funções legítimas, o BM prescreveu uma reforma do Estado centrada em sete ações: racionalização da burocracia estatal (modernização técnica, redução de pessoal, salários condicionados à produtividade etc.); ajuste fiscal; aperfeiçoamento da estrutura administrativa e legal necessária à privatização de empresas públicas; transferência da prestação de serviços públicos para ONGs; reforma do Judiciário, com o propósito de baratear custos judiciais, facilitar o acesso à Justiça e otimizar as relações de mercado; legislação favorável à livre circulação de capital financeiro; garantia dos direitos de propriedade. Junto com uma abertura econômica radical ("terapia de choque" em dois anos), recomendou também políticas compensatórias seletivas, reafirmando que a redução da pobreza viria com o crescimento e o posterior efeito derrame, pois "quando os mercados são eficientes, geralmente a equidade aumenta de forma espontânea" (ibidem:161).

Em outras palavras, ainda que continuasse a ser visto como um "problema", o Estado começava a ser reconhecido como indispensável para o impulso e a sustentação da liberalização econômica. A dicotomia Estado versus mercado, típica do enfoque hipermercadista dos anos 1980, começava a dar lugar a uma visão mais complementar.

A terceira coordenada consistiu na incorporação do "meio ambiente" ao programa político dominante. Com efeito, no início dos anos 1990 o $\mathrm{BM}$ havia se tornado politicamente vulnerável às críticas ao passivo socioambiental dos seus projetos de infraestrutura e energia (Rich, 1994; George e Sabelli, 1996; Caufield, 1996). Para sair da defensiva, o BM começou então a falar em "administração ambiental", buscando se afirmar como liderança internacional nessa área.

Publicado um mês antes da Conferência das Nações Unidas para o Meio Ambiente, o RDM 1992 tinha o propósito de compatibilizar a consigna do "desenvolvimento sustentável" com as exigências do programa neoliberal. O relatório afirmava a reciprocidade entre crescimento econômico e preservação ambiental, na medida em que somente com o crescimento da economia seria possível não apenas arcar com os custos da proteção ambiental, mas também diminuir a pressão social sobre a natureza. Argumentava também que a escassez de recursos naturais 
criaria uma demanda por pesquisas direcionadas a superar os obstáculos ao crescimento econômico. A idealização do poder da tecnologia que dava suporte a essa visão projetava um cenário irreal em que todos ganhariam, desde que os governos adotassem políticas pró-mercado. Ademais, a exaltação de estratégias do tipo "todos ganham" e a negação de trade-offs escamoteavam a "injustiça ambiental" que marca as sociedades contemporâneas, em particular na periferia, caracterizada pela concentração de poder na apropriação dos recursos socioambientais e na imposição da maior carga dos danos ambientais a populações de baixa renda e grupos étnicos subalternos.

Ao responder às críticas ambientalistas, o BM internalizou o "meio ambiente" no programa político dominante, convertendo-o numa nova frente de atuação. Afirmando que o "desenvolvimento sustentável" poderia não ocorrer sem o uso econômico eficiente do meio ambiente, o BM passou a impulsionar a transformação das regras e instituições ambientais na direção da mercantilização, utilizando condicionalidades para impelir os Estados-clientes a reestruturar agências públicas, reescrever legislações nacionais de água, terra e florestas e adotar protocolos científicos coerentes com o livre comércio de "ativos" ambientais (Goldman, 2005:121-131; Wade, 1997a:711).

A quarta coordenada definida pelo BM funcionou como elemento de ligação entre todas as demais e consistiu na entronização da ideia de governança (governance). O termo foi introduzido no vocabulário da Instituição por um relatório sobre a implementação do ajuste estrutural na África Subsaariana. A mensagem central era de que, além de políticas macroeconômicas "sólidas" e infraestrutura "eficiente", a construção de um ambiente favorável ao crescimento do setor privado dependia da "boa governança", entendida como instituições públicas "eficazes" e um novo "balanço entre governo e governados" (BM, 1989:xiii). De acordo com o informe, os programas de ajuste não haviam dado certo na região devido à "má" governança entre os atores públicos e privados. Desde então, essa tem sido a resposta dada pelo $\mathrm{BM}$ aos críticos do ajuste.

Em 1992, o BM publicou o primeiro informe dedicado ao tema, centrado na mensagem de que a engenharia institucional e a qualidade da gestão pública eram cruciais para a execução do ajuste. As premissas do enfoque "amistoso com o mercado" foram reiteradas e governança foi definida como a "maneira pela qual o poder é exercido na adminis- 
tração de recursos sociais e econômicos de um país para o desenvolvimento" (BM, 1992:1). Para a criação de um ambiente propício à liberdade do capital, já não bastavam políticas econômicas "sólidas"; era necessário adequar os marcos legais e melhorar a qualidade da administração pública como um todo.

O informe delimitou quatro áreas estratégicas de governança: administração pública, responsabilização (accountability), estrutura legal e transparência e informação. A boa governança resultaria da combinação de quatro fatores: a) eficiência na administração dos recursos públicos e na provisão de serviços; b) sistemas de responsabilização eficazes; c) disponibilidade de informação adequada e confiável para os agentes privados e; d) prioridades de governo "orientadas ao mercado" (BM, 1992:9). Traduzindo: ajuste fiscal e delimitação de novas prioridades de gasto público, cobrança de taxas em serviços públicos e estabelecimento de um marco legal previsível para os atores econômicos de maior gravitação, independente dos governos de plantão e dos parlamentos.

A tese de que a eficácia da gestão pública depende da articulação entre agências estatais e organizações sociais trouxe consigo a evocação à participação da "sociedade civil" como um dos componentes indispensáveis à boa governança. Todavia, "sociedade civil" foi tomada como sinônimo de associações voluntárias e ONGs. De modo geral, sindicatos, movimentos populares, camponeses e indígenas ficaram de fora.

A exaltação da importância das ONGs para a boa governança já tinha vertebração nas operações do BM. Com efeito, a entrada de ONGs no ciclo de projetos da Instituição havia crescido desde 1980, alcançando quase metade deles em 1994. Em larga medida, esse processo resultava da permeabilidade crescente entre o campo das ONGs e a indústria da assistência internacional ao desenvolvimento. À medida que a competição, a institucionalização e a profissionalização se impunham como imperativos no campo da ajuda ao desenvolvimento, e à medida que avançava o ajuste fiscal e a reestruturação das políticas nacionais, abria-se enorme espaço de atuação para ONGs preparadas para desempenhar funções arrancadas dos Estados nas áreas social e ambiental de forma especializada e sob a condição de atores terceirizados (Davis, 2006:83-84; Dezalay e Garth, 2005:288-300). Em pouco tempo, ativistas transformaram-se em especialistas em leis e gestores de proje- 
tos, buscando credenciais para negociar com círculos políticos e empresariais a captação de fundos e a gestão de "boas práticas". O novo perfil profissional do pessoal de ONGs se converteu em condição de reconhecimento e capital valorizado no mercado internacional de consultorias da indústria da ajuda, que movimenta mais de US\$ 1 bilhão por ano (Guilhot, 2005:215-217). Participar de projetos financiados pelo BM virou passaporte de entrada ou promoção nesse novo mercado. A partir de então, cada vez mais a colaboração entre o Banco e as ONGs envolveria a contratação de especialistas em "participação social" (Kapur et al., 1997:375).

A imbricação de ONGs nas operações do BM ao longo da década não foi um processo isento de contradições. A cultura organizacional do $\mathrm{BM}$ por muito tempo o havia fechado a qualquer colaboração com ONGs, vistas como celeiros de amadores, ativistas e sabotadores. O reconhecimento das ONGs como atores legítimos das políticas de desenvolvimento resultou não apenas da capacidade delas de se adaptarem ao novo contexto econômico e político, mas também da construção de conhecimento, eficiência e conexões com a academia e a indústria da ajuda, gerando um tipo de capital valorizado pelo BM (Guilhot, 2005:218). Aos poucos, o BM estava se tornando uma organização mais aberta, e isso não deve ser lido como uma guinada para tão somente cooptar os seus críticos - ainda que a estratégia de colaborar com ONGs ajudasse a limitar o âmbito das críticas (Williams e Young, 2007:208; Dezalay e Garth, 2005:282).

Ao longo dos anos 1990, então, a agenda da governança ganhou centralidade na atuação do BM. Que fatores levaram à sua emergência? A resposta deve considerar ao menos quatro aspectos.

O primeiro tem a ver com o aprendizado institucional decorrente da própria implementação do ajuste. Em meados dos anos 1980, em sintonia com o mainstream neoclássico, a visão predominante no BM era de que o Estado era apropriado por governantes, políticos e burocratas em busca de seus próprios interesses. A relação entre Estado e mercado era vista como antagônica e o Estado era considerado o responsável pela decadência econômica. Como mostrou Williams (2008:58-60), esse argumento justificava estratégias cada vez mais intrusivas contra a soberania nacional. Contudo, à medida que o ajuste estrutural avançava, os resultados largamente ficavam aquém das expectativas do BM. Por quê? O instrumento para induzir mudanças de políticas era o 
empréstimo condicional, que tinha limitações, pois os Estados-clientes acabavam recebendo as parcelas mesmo sem cumprir integralmente as exigências, entre outras razões, porque a entidade priorizava esse tipo de operação. Gradativamente, tornou-se claro para a administração do BM que o uso de "incentivos" dessa natureza não estava funcionando, em função de "obstáculos internos". Onde "dava certo"? Onde havia coalizões de poder bem organizadas e comprometidas com o ajuste. $\mathrm{O}$ reconhecimento dessa situação levou o BM a valorizar a "apropriação" (ownership) da pauta do ajuste por governantes, burocracias e grupos sociais específicos, e a construir estratégias para gerar essa apropriação. O objetivo era tornar o ajuste algo gestado "dentro" das sociedades, percebido como um produto endógeno, em torno do qual houvesse ampla concordância.

Por outro lado, mesmo onde "dava certo", a estabilização macroeconômica não era acompanhada pelo aumento da produtividade da economia. No início dos anos 1990, economistas do BM começaram a insistir que a principal razão para a baixa resposta do setor privado ao ajuste era a qualidade da estrutura institucional na qual o setor operava. Isso trouxe para a pauta da entidade questões como sistemas legais, contratos, mecanismos de regulação, sistemas de financiamento e informação etc. (Williams, 2008:61). Esse giro dos economistas para as instituições evocava a centralidade do Direito para a construção de economias de mercado (Dezalay e Garth, 2005:265).

O segundo aspecto, ligado ao anterior, foi a ascensão da Nova Economia Institucional (NEI) fora e dentro do BM. Essa corrente de pensamento teve origem na análise organizacional e abriu caminho como variante da teoria neoclássica nos anos 1960, ganhando enorme alento com a difusão dos trabalhos de Mancur Olson e Oliver Williamson. Contudo, a consagração veio com a premiação do Nobel de Economia para Ronald Coase (1991) e Douglass North (1993) ${ }^{3}$.

Para esse ramo de conhecimento, instituições são regras do jogo formais e informais criadas pelos indivíduos que dão forma à interação social, definem e limitam o conjunto de escolhas individuais, reduzindo incertezas e estruturando incentivos ao prover estabilidade às relações (North, 1993:13-14). Centrada no individualismo metodológico e no conceito de "escolha racional", a NEI parte do pressuposto de que a empresa capitalista, entendida mais como estrutura de gestão do que de produção, constitui o modelo de organização racional e eficiência 
não apenas para o conjunto da sociedade, mas também para a administração pública. A partir da naturalização da forma capitalista liberal, preconiza a segurança legal dos direitos de propriedade e a garantia plena do seu usufruto como requisitos para a eficiência econômica, a qual, por sua vez, depende da redução dos custos de transação associados a transferência, captura e proteção dos direitos de propriedade. Em mercados considerados imperfeitos, parte desses custos se refere à obtenção das informações necessárias para os atores orientarem suas ações e à assimetria com que são apropriadas pelos que participam das trocas, razão pela qual a informação é considerada incompleta. A NEI trabalha também com o conceito de "busca de renda" (rent seeking) para designar indivíduos e grupos orientados para a apropriação de rendas originadas da intervenção do Estado no mercado.

Costurando todo o acervo conceitual está a ideia de que as regras do jogo - as instituições - vigentes num dado ambiente determinam as condições para o exercício da escolha racional, a definição dos direitos de propriedade, os custos de transação, o acesso e a qualidade da informação e a apropriação distorcida de renda provocada pela ação do Estado. Os ambientes podem ser mais ou menos "eficientes", conforme a sua funcionalidade à "economia de mercado" (diminuição dos custos de transação, livre concorrência, segurança dos contratos e da propriedade privada etc.). Conclui-se, então, que a definição e o manejo das regras do jogo e do arranjo institucional são fatores decisivos para a eficiência econômica. Como já assinalado por diversos autores (Vilas, 2012; Carroll, 2010; Álvarez, 2004), tal abordagem tende a reduzir o institucional a uma dimensão técnica e instrumental. Além disso, por esse mesmo caminho, toma-se o político como mera engenharia institucional, o que permite internalizá-lo como fator de promoção da "economia de mercado". Desse modo, o institucional é instrumentalizado e subordinado à liberalização econômica, construída a partir de relações de poder aceitas como algo dado.

O impacto da NEI na pesquisa do BM foi sentido no relatório de 1992 sobre governança e desenvolvimento e jogou um papel importante na valorização do tipo de capital acumulado por ONGs, impossível de ser reconhecido enquanto o ambiente estivesse saturado pela ortodoxia macroeconômica. Mas foi no relatório sobre o desenvolvimento industrial dos países do sudeste da Ásia (BM, 1993) que a ressonância da NEI foi mais notadamente sentida. 
A preparação do estudo foi objeto de intensa disputa - já delineada em 1991 - entre a ortodoxia neoliberal, comandada pelos EUA, e a proposta de desenvolvimento "orientado pelo Estado", encabeçada pelo Japão (Berger e Beeson, 1998). Segundo os japoneses, o sucesso do país que, no início dos anos 1990, tornou-se a maior economia industrial do mundo - e de países como Taiwan e Coreia do Sul se sustentava na forte regulação do setor financeiro e numa política industrial cujo sistema de incentivos incluía, entre outros componentes, o direcionamento do crédito público subsidiado a indústrias estratégicas intensivas em tecnologia.

Para o BM, as receitas japonesas contrastavam com a defesa da liberalização financeira e da privatização de empresas públicas. Como assinalou Wade (1997:352), "dado que as ideias do Banco derivam em grande parte do interesse dos EUA pela liberdade de mercado, assim como das ideias vigentes a esse respeito neste país, o desafio do Japão contra o Banco era também um desafio contra os EUA". O governo japonês, que já havia criticado abertamente a orientação neoliberal do RDM 1991, instou a diretoria do BM para que considerasse a experiência do sudeste asiático, solicitando a realização de um estudo sobre o tema.

Como técnica de persuasão, o relatório jogou com uma dualidade falsa - laissez-faire $x$ intervencionismo estatal - frente à qual o enfoque "amigável com o mercado" aparecia como um constructo intermediário e equilibrado. O informe reconheceu, com ressalvas, a importância estratégica do planejamento e da ação estatal na orientação e sustentação do crescimento industrial naqueles países, mediante políticas setoriais ativas, concessão seletiva de crédito subsidiado, acordos entre agências governamentais e empresas privadas, protecionismo comercial seletivo, regulação da conta capital e poupança interna forçada. Porém, argumentou que tais intervenções haviam funcionado porque não foram "excessivas" (BM, 1993). Além disso, insistiu no caráter específico daquela experiência, advertindo que não estava "demonstrado" que aquele rol de políticas poderia ser replicado em outras regiões. Sugeriu também que os êxitos econômicos seriam alcançáveis sem aquele tipo de ação estatal. Ressaltando que o êxito daquela trajetória se devia mais à orientação exportadora da economia do que a modalidades específicas de gestão estatal, o relatório acentuou o lado mais convencional da ação estatal posta em prática, como o investimento em "capital humano" e infraestrutura. Ao final, aquela experiência foi apresentada como o resultado da combinação sui generis da teoria neo- 
clássica com o enfoque "amigável com o mercado". Como ironizou Amsden (1994:627), ao projetar o seu próprio reflexo no "sucesso" do sudeste asiático, o BM comportava-se como Narciso diante do espelho.

Para além da polêmica, o fato é que o relatório reconhecia a importância do papel dos governos asiáticos na criação de uma burocracia qualificada e de um "ambiente institucional" seguro e lucrativo para o investimento privado. Ele confirmava o foco na boa governança, entendendo-a como ação de governo capaz não apenas de coletar e usar informação econômica, mas também de administrar suas ligações com grupos sociais específicos (Williams, 2008:84).

O terceiro aspecto relevante decorreu da necessidade de melhorar a qualidade dos resultados dos projetos financiados pelo BM. O debate sobre a efetividade das ações da entidade ganhou projeção no início dos anos 1990, culminando em uma avaliação interna sobre a qualidade dos seus projetos conhecida como relatório Wapenhans (BM, 1992a). O trabalho analisou 1.300 projetos em curso em 113 países. As conclusões eram deploráveis para uma instituição cuja legitimidade se amparava na imagem da "excelência técnica" - utilizada para justificar um orçamento administrativo de mais de US\$ 1 bilhão por ano. Detectou-se a deterioração contínua da qualidade dos projetos em todos os setores entre 1981 e 1991. Em particular, algumas cifras chamavam atenção: 37,5\% dos projetos não apresentavam resultados "satisfatórios", e somente $22 \%$ estavam de acordo com as normas do próprio BM. A avaliação responsabilizou o que chamou de "cultura de aprovação", resultante de um sistema de incentivos burocráticos estruturado para a realização de operações financeiras independentemente da importância e dos impactos dos projetos. Por outro lado, o relatório salientava a capacidade administrativa, organizacional e técnica dos Estadosclientes, bem como a "participação social" (de ONGs, associações voluntárias e dos próprios beneficiários), como fatores decisivos para a efetividade dos projetos. Esses aspectos institucionais já vinham sendo advogados pelo Departamento de Avaliação de Operações do BM desde a década anterior. O relatório nunca foi publicado, mas tornou-se amplamente conhecido pelo staff. $\mathrm{O}$ seu vazamento municiou os críticos, contribuindo para abalar a imagem do BM como depositário de excelência técnica. Contudo, paradoxalmente, isso ajudou a chancelar internamente a ideia de "boa governança".

O quarto aspecto tem a ver com a dimensão política que cerca a agenda da "boa governança". Com efeito, essa agenda se tornou possível pelo 
uso crescente dos empréstimos de ajustamento estrutural, que deram às instituições de Bretton Woods instrumentos para reformar as políticas dos Estados-clientes. Além disso, ela ganhou impulso particular pela combinação do fim da Guerra Fria com a euforia da globalização financeira, que eliminou os constrangimentos políticos dos Estados Unidos e demais doadores em "consertar" a infraestrutura institucional dos estados. Dali em diante, a totalidade das políticas domésticas praticadas na periferia deveria se liberalizar. Assim, governança passou a ser o slogan geral que aglutinava políticas, técnicas e saberes necessários para impulsionar e dirigir a mudança social dentro dos estados sem o exercício de controle político direto (Williams e Young, 2007:216). É revelador que, ao mesmo tempo, o discurso das principais potências se tornasse idêntico. Entre 1990 e 1992, as agências de ajuda externa ao desenvolvimento dos Estados Unidos e do Reino Unido adotaram a agenda da governança e passaram a prescrevê-la. Outros doadores bilaterais fizeram o mesmo, como a França e a Alemanha, além de agências multilaterais. Em 1991, o tema apareceu pela primeira vez num comunicado do G7 (Williams, 2008:75-76; Babb, 2009:158). O termo apelava para a ideia de que todos ganhariam com instituições nacionais sólidas.

A agenda da governança veio ligada à promoção da "democracia de mercado", impulsionada pelo governo americano. Rapidamente, tal categoria foi tomada pela "comunidade internacional" como condição de reconhecimento e parâmetro de avaliação da qualidade do regime político e da engenharia institucional dos países da periferia. Para Washington, já não era mais necessário sustentar regimes ditatoriais impopulares, nem tolerar desvios ou vacilações quanto à liberalização econômica. Não por acaso, durante o governo Clinton os EUA se envolveriam em 48 intervenções militares, muito mais do que as 16 havidas durante toda a Guerra Fria (Fiori, 2004:97).

Ironicamente, enquanto grande parte da literatura sobre a transição democrática na América Latina exaltava a restrição das atribuições do Poder Executivo em favor do Legislativo e do Judiciário, a prosaica construção das "democracias de mercado" exigia alto grau de concentração do poder (insulation) na cúpula governamental e em órgãos estratégicos do Estado (Vilas, 2000:23). Desse ponto de vista, o manejo da liberalização econômica e da privatização devia estar sob a responsabilidade de uma equipe técnica impermeabilizada contra pressões sindicais, político-partidárias e demandas "populistas" (corporativas, 
protecionistas) de frações do empresariado doméstico. Assim, a divisão de trabalho prescrita pelo BM na primeira metade dos anos 1990 comportava dois pavimentos: no inferior, no âmbito de projetos e políticas sociais e ambientais, a colaboração entre Estado, setor privado, ONGs e instituições multilaterais; no superior, insulamento da política macroeconômica e das privatizações contra o debate parlamentar e reivindicações democráticas.

\section{REFORMAS DE SEGUNDA GERAÇÃO E "RETORNO DO ESTADO"}

O avanço da liberalização parecia inexorável, até que veio a crise do México em 1994-1995. A partir de então, o BM passou a advogar um novo estágio de ajuste estrutural, centrado na reforma do Estado e das instituições, em particular na América Latina (BM, 1996; Burki e Perry, 1997 e 1998, Naím, 1996). A rigor, porém, tal avaliação não se restringia a uma região específica. Prova disso foi o RDM 1997, dedicado ao tema do Estado. Publicado pouco antes da eclosão da crise financeira no sudeste da Ásia, tratou-se do primeiro RDM produzido integralmente sob a gestão de James Wolfensohn (1995-2005) e de Joseph Stiglitz como vice-presidente e economista-chefe do Banco. Clamando por um Estado "efetivo", o informe foi apresentado como um guia que "trazia de volta" o Estado. A própria indicação de Stiglitz expressou a aceitação dentro e fora do BM da importância do papel do Estado para a economia de mercado ${ }^{4}$.

A irrupção da crise financeira asiática alimentou ainda mais a onda de insatisfação com o Banco. Stiglitz e Wolfensohn conseguiram desviar parte das críticas dirigidas ao BM ao questionarem publicamente a pressão que o FMI havia feito pela liberalização financeira dos países em crise. No conjunto, seus pronunciamentos buscaram diferenciar a posição do BM do "fundamentalismo de mercado" do FMI. Tal discurso manejou a ideia de "retorno do Estado" - mote do RDM 1997 - como evidência da alegada distinção entre o BM e o FMI.

Todavia, longe de romper com o programa neoliberal, o RDM 1997 constituiu-se em uma peça importante da sua reciclagem e expansão (Hildyard, 1998; Guilhot, 2005; Craig e Porter, 2006). O rechaço à tese do "Estado mínimo" fez crer, para muitos, que estava em julgamento algo que, na verdade, nunca existiu. Com efeito, a liberalização econômica ensejou e requereu não a minimização, mas sim um redirecionamento e até fortalecimento da ação do Estado em favor das frações fi- 
nanceiras mais globalizadas e da ofensiva patronal contra direitos sociais e trabalhistas (Harvey, 2007; Jessop, 2008).

Num plano mais geral, o informe reiterou todas as premissas neoclássicas fundamentais. Seguindo a mesma linha do RDM 1991, repetiu-se a tese da complementariedade entre "Estado e mercado", definindo o Estado como um "parceiro, catalisador e facilitador" do crescimento econômico conduzido, sempre, pelo setor privado. Somente em situações excepcionais o Estado poderia corrigir "falhas de mercado eventuais".

O RDM 1997 propôs uma estratégia de reforma baseada em duas diretrizes. A primeira consistia em ajustar a função do Estado à sua "capacidade", o que implicava definir o seu rol legítimo de ações: garantir a estabilidade macroeconômica, assegurar um ambiente econômico "não distorcido" (sem controle de preços, subsídios etc.), estabelecer um marco legal claro e adequado à livre concorrência, investir em infraestrutura e em serviços sociais básicos (educação primária e saúde), proteger a propriedade privada, conservar o meio ambiente e promover programas sociais focalizados de alívio da pobreza. A mensagem era clara: "além do básico, não é preciso que o Estado seja o único provedor" (BM, 1997:6). A segunda diretriz consistia em aumentar a capacidade do Estado por meio do "revigoramento" das instituições públicas, implicando: a) a criação de normas que limitassem a "ação arbitrária" da burocracia estatal; b) a introdução de maior pressão competitiva no interior do Estado, por meio da criação de uma burocracia baseada no mérito, "enxuta" e bem remunerada, e da concorrência na provisão de bens e serviços entre o setor público, empresas e ONGs; c) a necessidade de "aproximar o Estado do povo", aumentando a "participação social" por meio de privatização ou terceirização da prestação e gestão de serviços sociais básicos, criação de conselhos deliberativos público-privados nos mais diversos âmbitos, realização de consultas regulares aos usuários de serviços, criação de conselhos comunitários para gerenciar escolas com mais "eficiência" e estimular o financiamento "voluntário" dos pais.

No âmbito da política social, o RDM 1997 diferenciou "seguro social" de "assistência social": o primeiro abarcava pensões, previdência, seguro-desemprego e outras modalidades voltadas a apoiar financeiramente pessoas que "ficam fora da economia assalariada durante uma parte da vida" (BM, 1997:58); a segunda abrangia programas destinados a "ajudar os elementos mais pobres da sociedade, aqueles que mal 
podem sustentar-se sozinhos" (idem). Segundo o relatório, a extensão do Estado de Bem-Estar teria ofuscado aquela distinção, gerando, ao longo do tempo, um sistema injusto - por beneficiar "assalariados do setor formal" e "funcionários públicos" (ibidem:60) - e insustentável do ponto de fiscal. Como solução, o BM propôs a separação clara entre seguro e assistência e a privatização do primeiro, uma vez que aposentadorias, pensões e seguros constituiriam uma forma de poupança, e não um direito, devendo, portanto, ser autofinanciável. Ao mesmo tempo, o BM prescreveu a reestruturação da assistência social, rechaçando a concessão de subsídios amplos para habitação, infraestrutura e alimentos em favor de medidas como a focalização de recursos em áreas com alta concentração de pobreza, microcrédito para pequenos negócios e, sobretudo, programas que exigissem o pagamento de taxas. Além disso, o BM indicou a necessidade de um trabalho ideológico intenso para "dar aos pobres condições para que se tornem advogados mais efetivos dos seus próprios interesses" (ibidem:63). ONGs e associações voluntárias cumpririam um papel fundamental nessa direção, com o propósito de legitimar o insulamento da política econômica pelo aumento da participação em áreas seguramente controladas. $\mathrm{O}$ tema da política industrial mereceu referências esparsas e minguadas, sem qualquer mudança em relação aos postulados anteriores.

Apesar de advogar um Estado "mais próximo do povo", o relatório não deixou de ressaltar novamente que um ambiente livre e aberto aos negócios depende de concentração e insulamento da autoridade em determinadas agências estatais contra "pressões particularistas". Por outro lado, devido ao fortalecimento da oposição à agenda neoliberal, o informe enfatizou a necessidade de um trabalho de persuasão mais consistente para conquistar a adesão de grupos sociais amplos.

Quanto ao papel dos organismos internacionais na reforma do Estado, o RDM 1997 delimitou quatro formas de atuação: a definição da pauta da reforma, a indicação de quadros próprios para a formulação de políticas, a provisão de recursos (reembolsáveis) para aliviar tensões sociais e dividir a oposição política e, por fim, a intermediação de acordos internacionais pró-liberalização, que serviriam para elevar os custos políticos dos governos que decidissem - ou fossem levados a trilhar uma rota alternativa de desenvolvimento.

O mantra básico da reforma econômica - desregulação, privatização e liberalização - se manteve inalterado e fora de questão (Anglade, 2000:59; Cornia, 1998:5). Não surpreende, pois, que um dos traços mais 
marcantes fosse a ausência de qualquer consideração séria sobre o poder e a política, resultando num tratamento administrativista do Estado (Kapur, 1998:4; Zurbriggen, 2007:164). Ao privar o Estado da sua dimensão intrinsecamente política e desligar os nexos históricoestruturais entre a ação estatal e a reprodução do capitalismo, o RDM 1997 buscava naturalizar a configuração de poder gerada por duas décadas de reestruturação neoliberal (Vilas, 2000:28).

Em conjunto, as prescrições do RDM 1997 convergiram para o que Gill (2002) denominou de "novo constitucionalismo": a promoção de reformas políticas e legais que redefinem a relação entre o político e o econômico por meio de uma série de mecanismos jurídicos vinculantes, com o objetivo de enquadrar e definir as regras dentro das quais a política "ordinária", convencional, pode se dar. Enquanto tal, o "novo constitucionalismo" retoma o papel "produtivo" da lei e da forma legal liberal na constituição da sociedade capitalista, evocando o império da lei para proteger a propriedade e a riqueza contra o controle democrático e a soberania popular.

Não por acaso, a NEI costurava todo o RDM 1997, favorecendo a reciclagem teórica e o alargamento do programa político do BM (Stolowicz, 2012; Álvarez, 2004; Carroll, 2010). De que maneira? Em primeiro lugar, ao justificar, com argumentos mais brandos e sofisticados, a separação e subordinação da política à economia. Uma vez que a diferença entre instituições eficientes e ineficientes consiste na sua funcionalidade à "economia de mercado", à racionalidade política cabe um papel subsidiário diante da racionalidade econômica. Nesse esquema teórico, a "economia de mercado" precede a política, de modo que o jogo político fica restrito, logicamente, à busca incessante pela diminuição de custos de transação. Além disso, nessa lógica, os resultados das políticas de ajustamento sempre poderão ser creditados, quando for da conveniência dos seus promotores, à má execução e à falta de convicção dos seus operadores locais.

Em segundo, por alimentar o discurso político do fim dos antagonismos estruturais e da harmonia de interesses. Classes, organizações da sociedade civil, grupos de interesse, movimentos sociais: todos são vistos como instituições que "interagem" para a obtenção de determinados fins e gravitam mais ou menos no mesmo nível de poder. O próprio Estado é tomado como mais uma instituição. Como a dominação e a exploração são desconsideradas, qualquer um pode se "empoderar" 
sem sofrer a obstrução de outrem. O poder deixa de ser visto como uma relação social entranhada numa estrutura social.

Em terceiro lugar, por alimentar a liberalização do Estado municiando os reformadores com um discurso mais palatável (Alvarez, 2004:48). Assim, por exemplo, em vez de o controle sobre o gasto público aparecer como um requerimento contábil calculado pela relação custobenefício, passava-se a tratá-lo como mais um meio de redução de custos de transação, independentemente da natureza das instituições. Afinal, não importa se públicas ou privadas, o que importa é que as "funções" e as "regras do jogo" sejam cumpridas cabalmente. Além disso, como todos os atores flutuam mais ou menos no mesmo patamar - uma vez que todos os indivíduos têm, abstratamente, capacidade igual para formar instituições -, a NEI fundamenta a política de que todos devem dar a sua cota, nivelando de forma arbitrariamente interessada atores estruturalmente desiguais.

Em quarto, a partir da ideia de engenharia institucional e de entorno institucional eficiente, a NEI favorece a legitimação de um novo patamar de negócios - envolvendo, por exemplo, a exploração de recursos naturais e energéticos - que alarga o espaço de valorização do capital, com argumentos que superam o hipermercadismo dos anos 1980 (idem).

Em resumo, em meados dos anos 1990, o programa político do BM incidia sobre o Estado, a economia, a sociedade civil e os indivíduos. Tratava-se de um projeto de transformação política, institucional e social abrangente, que englobava economia, administração pública, instituições e a construção da sociedade civil com atitudes "corretas". Cabia à "boa governança" articular todas essas esferas (Williams, 2008:86). Retomando Polanyi (2000), pode-se dizer que, da perspectiva do BM, mais do que nunca uma "economia de mercado" requeria uma "sociedade de mercado".

\section{O LANÇAMENTO DO PÓS-CONSENSO DE WASHINGTON}

Com a metástase da crise na Ásia Oriental, iniciou-se uma troca de acusações no interior do establishment oficial e privado americano, com propostas diversas sobre a adequação das bases institucionais que regulam as transações financeiras. Entre 1998 e 2000, avolumaram-se críticas ao CW dentro da sua própria base de sustentação (Naím, 2000). Os ataques de Stiglitz (1998) ao "fundamentalismo de mercado" do FMI - e, por extensão, ao Tesouro americano e à Wall Street (Wade e 
Veneroso, 1998) - compuseram esse mosaico. Em abril de 1998, Wolfensohn declarou que o CW havia terminado. Segundo ele, embora continuasse imprescindível a manutenção de políticas "já provadas", impunha-se uma "nova" agenda, centrada na promoção da "inclusão social" e da "participação", focadas na educação básica e na saúde primária. Por outro lado, em meio aos debates, o próprio Williamson (1998) revisou o CW, insistindo na sua replicação, mas acrescentando a necessidade de "fortalecer as instituições" (por exemplo, banco centrais independentes, comissões orçamentárias insuladas etc.) e "melhorar a educação básica".

Dentro do BM se abriu uma disputa entre duas correntes. Uma, mais ortodoxa, defendeu a realização de reformas institucionais que complementassem a agenda macroeconômica do CW e que fossem além dela, a fim de garantir a sua eficácia e consolidação. Seus expoentes mais notórios foram Burki e Perry (1997 e 1998). No conjunto, essa corrente limitou-se a reiterar o enfoque de 1991, dedicando-se a completá-lo e aprofundá-lo (Stolowicz, 2012; Vilas, 2000).

Outra vertente, mais heterodoxa, advogou uma visão "mais ampla de desenvolvimento" e preconizou um novo consenso, batizado de PósCW. Seu expoente mais célebre foi Stiglitz (1998, 2000 e 2000a). Criticando o CW por ter um foco muito estreito, defender políticas incompletas e, às vezes, equivocadas, Stiglitz estabeleceu dois grandes objetivos interligados: ampliar a concepção de desenvolvimento incorporando metas como equidade social, educação, inovação tecnológica, proteção ambiental, participação social e superação do "tradicionalismo" na vida social - e melhorar o "funcionamento dos mercados". Para alcançá-los, também seria preciso realizar uma segunda geração de reformas estruturais que promovesse: a) a criação de um marco legal e instrumentos de regulação que fortalecessem o sistema financeiro e estimulassem a concorrência em todos os setores da economia, pois só assim faria sentido avançar no processo de liberalização e privatização; b) a focalização do Estado na construção de "capital humano" (educação básica) e na montagem de "redes de proteção" aos mais pobres; c) a criação de mecanismos de organização e participação social que transformassem hábitos, comportamentos e valores individuais e coletivos e articulassem toda a sociedade no processo de mudança.

De acordo com Stiglitz, a realização dessas e de outras medidas demandaria um enfoque mais "flexível" sobre os setores e as atividades 
que devem ficar sob controle do Estado e do setor privado. Assim, partindo do pressuposto de que ao Estado cabe, antes de tudo, complementar os mercados, propôs que o Estado corrigisse falhas de mercado quando necessário, atuando temporariamente como um "catalisador" para resolver problemas de escassez de oferta de determinados bens e serviços. Porém, assim que os problemas fossem sanados, a atividade deveria ser concedida ou devolvida ao setor privado.

Para Stiglitz, o Pós-CW deveria ser assimilado por grupos dirigentes nacionais e convertido numa plataforma de mudanças apoiada por ampla coalizão social. Somente a partir dessa "interiorização" poder-se-ia articular o melhor formato e sequenciamento das reformas; do contrário, os conflitos internos e a paralisia prevaleceriam.

Comparada às proposições de Burki e Perry, a vertente encabeçada por Stiglitz se distanciou mais da ortodoxia neoclássica, enfatizando a necessidade de o Estado corrigir "falhas de mercado" e orientar os agentes econômicos em determinados aspectos. Entretanto, em termos teóricos, Stiglitz inovou pouco, uma vez que não abandonou as premissas fundamentais do mainstream (Fiori, 1999; Fine e van Waeyenberge, 2006). Com base no individualismo metodológico, elaborou uma compreensão da economia capitalista como um constructo de indivíduos informados imperfeitamente, coordenada de maneira também imperfeita pelo mercado, mas que pode e deve se aproximar do modelo neoclássico de concorrência perfeita. Ademais, ao explicar as relações econômicas a partir dos seus microfundamentos, deixou de lado conceitos como classe, poder e estrutura social.

A intervenção de Stiglitz não ofereceu uma saída teórica e política para a camisa de força imposta pela restauração liberal-conservadora (Fiori, 1999:40), servindo mais à defesa de uma "regulação pragmática dos mercados" do que à construção de uma alternativa efetiva ao neoliberalismo, condensado, de forma estilizada, no CW (Vilas, 2000:34). Por outro lado, Stiglitz não esclareceu que agentes sociais poderiam levar adiante a sua proposta. Tudo se passa como se o desenvolvimento se resumisse à ampliação de metas e ao emprego de instrumentos adequados, sem qualquer mudança nas relações de poder político e econômico vigentes nos âmbitos nacional e internacional. Ainda assim, suas críticas ao CW e, sobretudo, à forma como o FMI - orientado pelo Tesouro - agiu frente à crise financeira na Ásia Oriental, soaram mal den- 
tro do establishment americano oficial e privado, tornando insustentável a sua permanência no BM (Wade, 2001a:116).

\section{O Marco Integral de Desenvolvimento}

No final dos anos 1990, o andamento das reformas estruturais estava praticamente paralisado nos principais "mercados emergentes", enquanto a eclosão de protestos "antiglobalização" dava visibilidade à insatisfação com as políticas neoliberais. Na América Latina, governos eleitos começaram a cair em série. Na Ásia Oriental, a crise financeira pauperizava milhões de trabalhadores.

Em resposta ao novo cenário e na esteira do Pós-CW anunciado por Stiglitz e por Wolfensohn, o BM concentrou a sua mensagem em dois grandes temas. O primeiro era o da urgência de que os governos implementassem mecanismos que aliviassem os efeitos socialmente regressivos da liberalização como parte do ajuste estrutural, a fim de garantir o apoio necessário à sua sustentabilidade política (cf. Wolfensohn, 1998:2-3).

O segundo tema era o da necessidade de um paradigma internacional de desenvolvimento que fosse além da agenda de reformas de primeira geração e englobasse os fundamentos sociais capazes de assegurar vida longa às novas configurações de poder nascidas com a neoliberalização. O assunto já havia sido esboçado no RDM 1997:

Nossa concepção das transformações econômicas necessárias é muito restrita; ao prestarmos mais atenção às cifras macroeconômicas ou às reformas de grande alcance, como a privatização, deixamos de lado a infraestrutura institucional básica, sem a qual uma economia de mercado simplesmente não pode funcionar. (...) Em uma economia globalizada, o que importa é a totalidade da mudança em um país. (Wolfensohn, 1998:5; tradução livre, ênfase no original)

Tal paradigma converter-se-ia em força material por meio de coalizões internacionais públicas e privadas centradas na obtenção de resultados pragmáticos e mensuráveis. A naturalização do projeto político dominante dependeria, assim, da conquista da hegemonia na sociedade civil. Por isso, Wolfensohn enfatizou a necessidade de se avançar na formação de visões de mundo e do próprio self individual em clave liberal: 
Devemos nos esforçar para estabelecer instituições oficiais e civis sólidas de alcance local, que inspirem confiança (...). Para criar instituições com tais características se requer algo mais do que a modificação das regras formais. Também é necessário mudar as regras e normas informais; é preciso formar as pessoas, estabelecer valores, desenvolver aptidões e criar incentivos que possam servir de apoio aos que estejam empenhados em conseguir a mudança. (Wolfensohn, 1999:8; tradução livre)

Com tais propósitos, Wolfensohn lançou em 1999 o Marco Integral de Desenvolvimento (Comprehensive Development Framework, CDF). O objetivo era estabelecer um quadro de políticas macroeconômicas, financeiras, estruturais, sociais e ambientais compartilhado por toda a "comunidade internacional". Os itens que dariam forma ao CDF eram os mesmos prescritos pelo BM há uma década. O sequenciamento e o ritmo da sua implementação dar-se-iam conforme as particularidades de cada país, a fim de potencializar o processo de transformação social e lhe dar condições de sustentabilidade (Wolfensohn, 1999:8). A “apropriação" (ownership) teria importância fundamental: a população deveria se identificar com os programas e projetos e caberia aos governos dirigi-los, se necessário com assistência externa. Por sua vez, o manejo do orgulho nacional e do sentimento de comunidade pela via da valorização da cultura local favoreceria a identificação e a adesão social. Por fim, a matriz de políticas de cada Estado que participasse do CDF seria - eis a sua inovação principal - monitorada em tempo real pelo BM e outras agências internacionais.

A noção de ownership foi tomada diretamente da administração de negócios e implica o compromisso dos empregados com os objetivos dos patrões. Na política internacional serve para ocultar a transformação e ampliação das condicionalidades, designando a internalização de doutrinas e prescrições a partir da adaptação criativa às circunstâncias locais (Taylor e Soederberger, 2007:466). Por isso, o BM passou a reconhecer a necessária margem de ação para que os governos nacionais lidassem com as contradições da liberalização, interagindo com a sociedade civil "responsável" e imbricando o setor privado diretamente na gestão pública ${ }^{5}$.

O CDF sintetizou uma década de alargamento e complexa politização da atuação do BM. Tal trajetória requereu adaptações na definição da própria entidade como instituição técnica e apolítica. De acordo com o 
seu estatuto de fundação, o BM não pode intervir na política interna dos Estados-membros, não pode pautar a autorização de empréstimos pelo caráter ou regime político do Estado-membro nem por considerações de ordem política; os Estados-membros, por sua vez, não podem usar a instituição como instrumento da sua política externa.

Malgrado tais limitações, ao longo da sua história, o BM sempre desempenhou um papel político, mantendo a fachada técnica (Brown, 1992; Kofas, 2005; Pereira, 2010). Contudo, a emergência da agenda da governança obrigou a Instituição a fazer uma interpretação ad hoc dos seus estatutos. No debate interno, duas tomadas de posição foram decisivas para chancelar o novo rumo (Burgos, 2007:19-20; Williams, 2008:70-82). A primeira consistiu numa definição estreita de temas considerados "políticos" e, portanto, fora da competência do BM. Eram eles: $i$ ) o tipo de regime político de um país; ii) o pertencimento a bloco de países e; iii) a dinâmica partidária nacional. Fora disso, restava aberta ao BM uma miríade de temas. A segunda medida foi o conceito emitido pelo departamento legal da Instituição, que estabeleceu que o BM podia intervir em determinados assuntos políticos, sempre e quando tivessem conotações econômicas. Tal postulado incluía: a) a instabilidade política e a incerteza quanto à capacidade de pagamento de um Estado; b) o não cumprimento de obrigações definidas pelo Conselho de Segurança da ONU; c) a existência de questões políticas que repercutam de modo direto, inequívoco e preponderante em aspectos econômicos relativos à missão do $\mathrm{BM}$. Com essa segunda medida, a "boa governança" foi tomada como meio para o desenvolvimento econômico, expandindo o mandato do BM.

\section{DÉCADA DE 2000: PÓS-CW E SEGURANÇA INTERNACIONAL}

Após ingerência e depuração conduzidas pelo Tesouro americano (Wade, 2001 e 2002), o RDM 2000-2001 prescreveu uma agenda de combate à pobreza que englobava: $i$ ) a promoção de oportunidades; ii) o fortalecimento da autonomia e do empoderamento dos pobres e; iii) a melhora da segurança (BM, 2001:33). Na primeira esfera, o relatório insistia que o ajuste era "bom para os pobres", desde que corretamente operado pelos governos. Estabelecido esse pressuposto, o informe arrolou o mesmo conjunto de medidas que vinha prescrevendo há uma década, entre as quais: a) a legalização dos bens imobiliários dos "pobres" para que servissem de garantia para a obtenção de empréstimos bancários; b) o investimento em "capacidades humanas" como saúde e 
educação básicas; c) a oferta de serviços públicos por meio de ONGs e empresas.

O segundo âmbito, fortalecimento da autonomia (ou empoderamento), implicava fomentar a mobilização dos "pobres" em organizações locais para que fiscalizassem as instituições estatais, participassem do processo decisório local e, assim, colaborassem para "assegurar o primado da lei na vida diária" (BM, 2001:39). Isso, por sua vez, implicaria a remoção de barreiras políticas, jurídicas e sociais que se erguem contra certos grupos sociais e os impedem de "ingressar efetivamente nos mercados" (idem), i.e., de servirem como força de trabalho plenamente explorável.

Por fim, melhorar a "segurança dos pobres" significava reduzir a sua "vulnerabilidade" a doenças, choques econômicos e catástrofes naturais, e habilitá-los a enfrentarem tais riscos. Como? Primeiro, criando-se um ambiente favorável aos negócios e ao crescimento econômico. Segundo, apoiando-se "o conjunto de recursos dos pobres (humanos, naturais, físicos, financeiros e sociais)" para que pudessem se dedicar a atividades mercantis de maior risco e rendimento "capazes de extraí-los da pobreza", seja como vendedores da sua força de trabalho, seja como produtores diretos. Terceiro, instituindo-se uma abordagem de "gestão de risco" que alternasse o uso de instrumentos diversos de política social conforme os riscos peculiares de cada grupo social, a fim de garantir portas de saída permanentes que assegurassem a exposição de cada um aos imperativos de mercado (ibidem:40). A exposição de indivíduos e grupos sociais ao risco da dependência do mercado deveria ser modulada permanentemente, com o objetivo de assegurar a sua disciplina e subordinação ao capital (Cammack, 2004 e 2009).

No ano seguinte, o RDM 2002 - dedicado ao tema da "construção de instituições para os mercados" - reafirmou o mesmo programa político, dentro de um marco teórico global baseado integralmente na NEI. O informe identificou três fatores responsáveis pela limitação das oportunidades de mercado a indivíduos e empresas: a) custos de transação elevados, derivados da falta de informação adequada; $b$ ) problemas de definição e observância dos direitos de propriedade; c) falhas de governo e de mercado que dificultam o ingresso de agentes econômicos mais eficientes e a saída de agentes menos eficientes. Para superar tais limitações, seria necessário criar ou aperfeiçoar instituições ca- 
pazes de: a) processar e difundir informações sobre situações de mercado, seus bens e participantes, de modo que os agentes econômicos tivessem clareza sobre o que está sendo transacionado; b) definir e fazer cumprir os direitos de propriedade e os contratos; c) regular a concorrência mercantil, no sentido de protegê-la juridicamente de instabilidades políticas, com o objetivo de estendê-la a todos os âmbitos da vida social (do individual ao coletivo, do rural ao urbano, da agricultura às finanças).

Seguindo as mesmas coordenadas estabelecidas 10 anos antes, o informe destacou que o crescimento econômico e a redução da pobreza não dependiam apenas de políticas macroeconômicas sólidas, mas também de instituições públicas adequadas e da boa governança entre o público e o privado. Enfatizou-se a necessidade de um Estado forte, capaz de garantir juridicamente as condições necessárias à atividade econômica privada. Todavia, diferentemente da centralidade atribuída pelo RDM 1997 à reforma do Estado, o Informe de 2002 diluiu o tema numa retórica mais geral em prol da reengenharia das instituições. A liberalização foi conceituada como um "agente catalisador da mudança institucional ao longo da história", de tal maneira que "os países abertos costumam ter também uma maior qualidade institucional" (BM, 2002:10). Não surpreende, pois, que temas como política industrial e regulação comercial e financeira tenham sido suprimidos.

Àquela altura, para Rodrik (2002), a agenda impulsionada pelo BM a partir de meados dos anos 1990 configurava uma espécie de "CW ampliado". A caracterização de Rodrik é útil ao identificar a reorientação do BM para assuntos de governança (local, regional, nacional e internacional), reforma do Estado, flexibilização da legislação trabalhista, homogeneização da arquitetura financeira internacional e aliviamento seletivo da pobreza. Nesse sentido, fica clara a aproximação entre a agenda do BM e a atualização do CW feita por Kuczynski e Williamson (2004).

Por outro lado, tal caracterização é insuficiente, pois deixa de lado três dimensões centrais. A primeira diz respeito ao "esverdeamento" do BM. Com efeito, a extensão das relações mercantis ao conjunto dos recursos naturais tornou-se estrategicamente tão importante na agenda da Instituição que, a partir de 1992-1993, o BM passou a impulsionar também o ajuste ambiental das políticas nacionais, com o objetivo de sintonizar e homogeneizar as normas públicas aos imperativos da liberalização econômica e da privatização (Goldman, 2005). 
A segunda diz respeito à agenda de segurança internacional impulsionada pelos EUA a partir de 11 de setembro de 2001. Por meio da doutrina da guerra preventiva e da promoção da democracia, segurança e humanitarismo vieram para o centro da agenda do BM, colando "pobreza" com "instabilidade global". O resultado foi uma síntese entre o $\mathrm{CW}$ ampliado e a guerra neoconservadora contra o terrorismo. Expressão desse movimento foi a ênfase do BM nos chamados "Estados falidos", em voga no mainstream acadêmico e político anglo-americano. Tais Estados se caracterizam por alta instabilidade política, conflitos internos ou transfronteiriços graves e paralisação ou colapso da autoridade pública e do sistema de tomada de decisões. Pelo seu trabalho junto a doadores bilaterais e multilaterais, fundações empresarialfilantrópicas e ONGs que constituem a indústria internacional da ajuda, o BM se tornou uma das forças mais proeminentes no negócio da "reconstrução pós-conflito" (Harrison, 2004; Williams, 2008; Babb, 2009).

A terceira dimensão diz respeito à internalização do "combate à pobreza" como mecanismo de reciclagem do neoliberalismo. Tal processo vem desde o início da década de 1990 e se materializou em instrumentos diferenciados. Os mais recentes são os Documentos Estratégicos de Redução da Pobreza (Poverty Reduction Strategy Papers, ou PRSPs), aplicados em países pobres altamente endividados. Cada PRSP deve resultar de um processo amplo e transparente de participação social que demarque a "luta contra a pobreza" como prioridade nacional. Tem de conter metas claras, definidas a partir da delimitação de um marco macroeconômico e de um roteiro de reformas estruturais consideradas adequadas para o investimento privado. Pontualmente, comporta programas focalizados de redução da pobreza. Cabe ao BM e ao FMI assessorarem os governos nesse processo de concertação social, de tal maneira que cada Estado assuma a autoria do "seu" PRSP, segundo o princípio da apropriação.

A elaboração dos PRSPs tem apresentado resultados politicamente favoráveis para o BM, por várias razões. A primeira é que, por meio deles, o BM assumiu a coordenação de toda a cooperação multilateral ao desenvolvimento nesses países. A segunda razão é que os PRSPs contribuíram para impor ou reforçar um modelo de política social centrado na privatização de serviços básicos (para os que podem pagar) e em transferências monetárias condicionadas e transitórias (para os que ainda não podem fazê-lo), fornecendo ao BM e à indústria da ajuda in- 
ternacional uma ferramenta adicional de construção política nos países pobres mais endividados que incide nas condições gerais de reprodução social ${ }^{6}$. A política de transferência monetária condicionada, assim, cumpre o papel de inserir crescentemente os mais pobres ao consumo, a partir da ideia de que cabe ao Estado desempenhar um papel ativo no fortalecimento do mercado, configurando o que alguns denominam de "neoliberalismo inclusivo" (Craig e Porter, 2006).

Os RDMs posteriores deram continuidade à reciclagem do programa neoliberal, ampliando-o e atualizando-o em áreas sensíveis. Em 2003, o RDM centrou-se na criação de modalidades de gestão ambiental favoráveis à mercantilização e ao livre comércio dos recursos naturais. Em 2004, abordou o tema dos marcos regulatórios necessários à prestação de serviços públicos, na linha das reformas de segunda geração. Por sua vez, o RDM 2005 articulou, em um enfoque global único, liberalização econômica, política tributária e flexibilização das leis trabalhistas. O de 2006 tratou da relação entre desigualdades socioeconômicas e desenvolvimento, articulando "empoderamento" e "clima de investimento". O RDM 2007 abordou o tema "juventude", ancorado nas categorias de capital humano e capital social ${ }^{7}$. O relatório de 2008 centrou-se no tema da agricultura para o mercado. Em 2009, o RDM apresentou uma versão da geografia econômica mundial contemporânea, dando ênfase a processos de urbanização e desenvolvimento territorial e sua relação com mercados. O de 2010 abordou novamente a relação entre meio ambiente e desenvolvimento econômico, incorporando o tema da mudança climática. Em 2011, o RDM foi dedicado à temática de "conflito, segurança e desenvolvimento". Em todos, respectivamente, o tema principal veio ancorado nos pilares do programa neoliberal reciclado pelo neoinstitucionalismo: blindagem da política econômica; boa governança entre Estado, setor privado e sociedade civil; apropriação; políticas de aliviamento da pobreza e participação social dos "pobres" em áreas seguramente controladas.

O programa político do BM seguiu avançando e se adaptando à nova situação internacional aberta pela crise econômica que se abateu em 2008 sobre os Estados Unidos, o Japão e a Zona do Euro. A crise deu novo combustível ao BM, que completou 70 anos em 2014, elevando a sua carteira de empréstimos ao seu máximo patamar histórico em 2009-2010, alavancado pelos empréstimos de ajuste. O teor das mudanças ditadas a diversos países pós-2008 - em parceria com o FMI evidenciou a vigência do programa político neoliberal em sua face 
mais dura, sustentada pela manutenção do predomínio firme dos EUA e seus principais aliados europeus sobre as instituições de Bretton Woods (cf. Wade, 2010 e 2013; Vestergaard e Wade, 2013; Andersen et al., 2006).

\section{CONCLUSÃO}

No último quarto de século, a atuação do BM tornou-se mais abrangente e intrusiva. Crescendo e fazendo mais mediante um processo contínuo de alargamento institucional e mudança incremental, o BM e sua trajetória foram modelados por um conjunto de fatores, entre os quais se destacam a política dos EUA - ela própria moldada por pressões diversas - para a entidade, as contradições da economia internacional e os debates no interior do pensamento econômico, além da própria dinâmica interna da instituição.

Sintetizado no CW, o programa da entidade se reciclou, expandiu e diversificou, uma vez que, além de prescrever a liberalização, a privatização e o ajuste macroeconômico, passou a impulsionar a reconstrução abrangente da economia, da relação sociedade-natureza, do Estado, da sociedade civil e do próprio self individual, em clave liberal, nos países-clientes. Ao mesmo tempo, o combate à pobreza foi incorporado pela instituição, abrangendo desde programas de alívio compensatório pontual (a partir do final dos anos 1980) a transferências de renda condicionadas e transitórias (que se difundem na década de 2000), acoplando-se como mecanismos auxiliares da desregulação e privatização das economias nacionais. As formas pelas quais tal programa tem se traduzido em operações do BM negociadas com os Estados-clientes variam profundamente, conforme o caso.

Durante todo o período, o BM explorou a sinergia entre dinheiro, prescrições políticas e conhecimento econômico para ampliar a sua influência e institucionalizar o seu programa em âmbito internacional, a partir da sua condição absolutamente singular de emprestador, formulador e articulador de políticas e veiculador de ideias e prescrições, em clave anglo-saxônica, sobre o que fazer em matéria de desenvolvimento capitalista.

A atuação do BM contribuiu para alargar o espaço de valorização do capital, ao mesmo tempo em que se acentuavam a volatilidade da economia internacional e os efeitos socialmente regressivos da liberalização em inúmeros países. Reciclado pelo neoinstitucionalismo, o seu 
programa político seguiu avançando e se adaptando às novas condições internacionais abertas pela crise de 2008 e seus desdobramentos.

(Recebido para publicação em agosto de 2013) (Reapresentado em fevereiro de 2014) (Aprovado para publicação em setembro de 2014) 


\section{NOTAS}

1. Como mostraram, a partir de abordagens distintas, Gwin (1997); Dezalay e Garth (2005); Harrison (2004); Goldman (2005); Woods (2006); Craig e Porter (2006) e Williams (2008).

2. O RDM é a publicação anual mais importante do BM desde 1978. É um documento político que transmite a mensagem principal da Instituição sobre assuntos-chave, porém sob a aparência da melhor pesquisa técnica. A sua realização consome cerca de 5 milhões de dólares. Cada edição tem pelo menos 50 mil exemplares em inglês e mais 50 mil traduzidos para sete idiomas. O trabalho leva em torno de 18 meses e envolve consultores externos e algum debate com ONGs sediadas nos principais Estados-membros do BM, sobretudo os EUA. Para detalhes, cf. Wade (2001).

3. A legitimidade acadêmica internacional alcançada pela NEI acabou por silenciar aqueles macroeconomistas que, dentro do BM, duvidavam que os neoinstitucionalistas fossem mesmo economistas (Dezalay e Garth, 2005:267).

4. Stiglitz já era mundialmente conhecido por seus trabalhos sobre economia da informação, que mostravam como, em condições de informação incompleta e, portanto, de mercados imperfeitos, o Estado tem um papel vital a cumprir.

5. No início da década de 2000, sob o patrocínio dos principais doadores e da Organização para a Cooperação e Desenvolvimento Econômico (OCDE), ocorre um processo mais geral - do qual o BM foi um ator de peso - no sentido de estabelecer coordenadas e protocolos comuns entre as organizações multilaterais e bilaterais da indústria da ajuda internacional. O corolário desse processo se materializou na Declaração de Paris sobre a Eficácia da Ajuda ao Desenvolvimento, de 2005, que estabeleceu como princípios a apropriação, o alinhamento, a harmonização e a gestão por resultados.

6. Cf. Ruckert (2009 e 2010), Thirkell-White (2009) e Crawford e Abdulai (2009). Vendidos como uma nova geração de programas sociais por terem melhor focalização, custos administrativos mais baixos e combaterem as causas da transmissão intergeracional da pobreza, os programas de transferências monetárias condicionadas, por princípio transitórios, tornaram-se bastante usuais em inúmeros países pobres e de renda média desde o início dos anos 2000, e o BM teve um papel importante nessa difusão. No Brasil, por exemplo, o Bolsa Família contou com assessoramento e financiamento do BM, e é por ele considerado exemplar (cf. BM, 2009).

7. Sobre a forma como o BM maneja a categoria de "capital social", cf. Fine (2007) e Harriss (2002). Sobre o debate interno ao BM a respeito do capital social e a organização burocrática da política social, ver, respectivamente, Bebbington et al. (2004) e Hall (2007). 


\section{REFERÊNCIAS BIBLIOGRÁFICAS}

ÁLVAREZ, Jairo E. (2004), Construcción del Modelo Neoliberal en Colombia (1970-2004). Bogotá, Aurora.

AMSDEN, Alice. (1994), “Why Isn't the Whole World Experimenting with the East Asian Model to Develop?: Review of The East Asian Miracle". World Development, vol. 22, no 4, pp. 627-633.

ANDERSEN, Thomas Barnebeck et al. (2006), "US Politics and World Bank IDA-Lending". The Journal of Development Studies, vol. 42, no 5, pp. 772-794.

ANGLADE, Christian. (2000), “El Estado del Banco Mundial”. Estudios Políticos, no 25, pp. 39-76.

BABB, Sarah. (2009), Behind the Development Banks: Washington Politics, World Poverty, and the Wealthy of Nations. Chicago/London, The University of Chicago Press.

(2013), “The Washington Consensus as Transnational Policy Paradigm: Its Origins, Trajectory and Likely Successor". Review of International Political Economy, vol. 20, no 2, pp. 268-297.

BANCO MUNDIAL. (1989), Sub-Saharan Africa: From Crisis to Sustainable Growth. Washington, DC, The World Bank.

. (1990), Informe sobre el Desarrollo Mundial. Washington, DC, The World Bank.

. (1991), Informe sobre el Desarrollo Mundial. Washington, DC, The World Bank.

. (1992), Governance and Development. Washington, DC, The World Bank.

. (1992a), Effective Implementation: Key to Development Impact. Washington, DC, The World Bank.

. (1993), The East Asian Miracle. New York, Oxford University Press.

. (1996), ¿Qué Significa para el Banco Mundial la Reforma del Estado? Washington, DC, The World Bank.

. (1997), Relatório sobre o Desenvolvimento Mundial. Washington, DC, The World Bank.

(2001), Relatório sobre o Desenvolvimento Mundial. Washington, DC, The World Bank.

. (2002), Informe sobre el Desarrollo Mundial. Washington, DC, The World Bank.

. (2009), Conditional Cash Transfers: Reducing Present and Future Poverty. Washington, DC, The World Bank.

BEBBINGTON, Anthony et al. (2004), "Exploring Social Capital Debates at the World Bank". The Journal of Development Studies, vol. 40, no 5, pp. 33-64.

BERGER, Mark T. e BEESON, Mark. (1998), "Lineages of Liberalism and Miracles of Modernisation: The World Bank, the East Asian Trajectory and the International Development Debate". Third World Quarterly, vol. 19, no 3, pp. 487-504.

BROWN, Bartram S. (1992), The United States and the Politicization of the World Bank. London/New York, Kegan Paul International. 
BURGOS, José. (2007), “El Banco Mundial y la Politización de su Mandato”. Análisis Político, no 59, pp. 3-23.

BURKI, Shahid J. e PERRY, Guillermo. (1997), The Long March: A Reform Agenda for Latin America and the Caribbean in the Next Decade. Washington, DC, The World Bank.

(1998), Más allá del Consenso de Washington: La Hora de la Reforma Institucional. Washington, DC, Banco Mundial.

CAMMACK, Paul. (2004), "What the World Bank Means by Poverty Reduction and Why it Matters". New Political Economy, vol. 9, no 2, pp. 189-211.

. (2009), "Poverty Reduction and Universal Competitiveness". Labour. Capital and Society, vol. 42, nos 1 e 2, pp. 32-54.

CARROLL, Toby. (2010), Delusions of Development. The World Bank and the Post-Washington Consensus in Southeast Asia. London/New York, Palgrave.

CAUFIELD, Catherine. (1996), Masters of Illusion: The World Bank and the Poverty of Nations. New York, Henry Holt.

CORNIA, Giovanni A. (1998), “Convergencia sobre Asuntos de Gobernabilidad, Disensiones sobre Políticas Económicas: Analizando el Informe del Banco Mundial de 1997". Instituciones y Desarrollo, no 2, pp. 1-10.

CRAIG, David e PORTER, Doug. (2006), Development Beyond Neoliberalism? Governance, Poverty Reduction and Political Economy. New York, Routledge.

CRAWFORD, Gordon e ABDULAI, Abdul-Gafaru. (2009), “The World Bank and Ghana's Poverty Reduction Strategies: Strengthening the State or Consolidating Neoliberalism?". Labour. Capital and Society, vol. 42, nos 1e 2, pp. 83-115.

DAVIS, Mike. (2006), Planeta Favela. São Paulo, Boitempo.

DEZALAY, Yves e GARTH, Bryant. (2005), La Internacionalización de las Luchas por el Poder. México, DF, UNAM.

FINE, Ben. (2007), “The Developmental State Is Dead: Long Live Social Capital?", in D. Moore (ed.), The World Bank: Development, Poverty, Hegemony. Scottsville, University of KwaZulu-Natal Press, pp. 121-143.

e VAN WAEYENBERGE, Elisa. (2006), “Corrigiendo a Stiglitz: De la Información al Poder en el Mundo del Desarrollo". Socialist Register 2006, pp. 185-209.

FIORI, José Luís. (1999), “De Volta à Questão da Riqueza de Algumas Nações”, in J. L. Fiori (org.), Estados e Moedas no Desenvolvimento das Nações (3a ed.). Petrópolis, Vozes, pp. 11-46.

. (2004), "Formação, Expansão e Limites do Poder Global", in J. L. Fiori (org.), O Poder Americano. Petrópolis, Vozes, pp. 11-64.

GEORGE, Susan e SABELLI, Fabrizio. (1996), La Religión del Crédito: El Banco Mundial y su Imperio Secular. (2a ed.). Barcelona, Intermón.

GILL, Stephen. (2002), "Constitutionalizing Inequality and the Clash of Globalizations". International Studies Review, vol. 4, no 2, pp. 47-65.

GOLDMAN, Michael. (2005), Imperial Nature: The World Bank and Struggles for Social Justice in the Age of Globalization. New Haven/London, Yale University Press.

DADOS - Revista de Ciências Sociais, Rio de Janeiro, vol. 58, nº 2, 2015 
GUILHOT, Nicolas. (2005), The Democracy Makers: Human Rights and the Politics of Global Order. New York, Columbia University Press.

GWIN, Catherine. (1997), “U.S. Relations with the World Bank, 1945-1992”, in D. Kapur et al. (eds.), The World Bank: Its First Half Century. Washington, DC, Brookings Institution Press, vol. 2, pp. 195-274.

HALL, Anthony. (2007), "Social Politics in the World Bank". Global Social Policy, vol. 7, no 2, pp. 151-171.

HARRISON, Graham. (2004), The World Bank and Africa. London/New York, Routledge.

HARRISS, John. (2002), Depoliticizing Development. London, Anthem Press.

HARVEY, David. (2007), Breve Historia del Neoliberalismo. Madrid, Akal.

HILDYARD, Nicolas. (1998), The World Bank and the State: A Recipe for Change? London, Bretton Woods Project.

JESSOP, Robert. (2008), El Futuro del Estado Capitalista. Madrid, Catarata.

KAPUR, Devesh. (1998), "The State in a Changing World: A Critique of the 1997 WDR". Working Paper 98-02, Harvard University. et al. (1997), The World Bank: Its First Half Century. Washington, D.C., Brookings Institution Press, vol. 1.

KOFAS, Jon. (2005), Independence from America: Global Integration and Inequality. Burlington, Ashgate.

KUCZYNSKI, Pablo e WILLIAMSON, John. (2004), Depois do Consenso de Washington: Retomando o Crescimento e a Reforma na América Latina. São Paulo, Saraiva.

NAÍM, Moisés. (1996), “Transição para o Regime de Mercado na América Latina: Dos Choques Macroeconômicos à Terapia Institucional", in C. Langoni (org.), A Nova América Latina. Rio de Janeiro, FGV Editora, pp. 211-263.

. (2000), “Washington Consensus or Washington Confusion?". Foreign Policy, no 118 , pp. 86-103.

NORTH, Douglass. (1993), Instituciones, Cambio Institucional y Desempeño Económico. México, DF, Fondo de Cultura Económica.

PEREIRA, João Márcio Mendes. (2010), O Banco Mundial como Ator Político, Intelectual e Financeiro (1944-2008). Rio de Janeiro, Civilização Brasileira.

POLANYI, Karl. (2000), A Grande Transformação: As Origens do Nosso Tempo (4a ed.). São Paulo, Campus.

RICH, Bruce. (1994), Mortgaging the Earth: The World Bank, Environmental Impoverishment, and the Crisis of Development. Boston, Beacon Press.

RODRIK, Dani. (2002), Depois do Neoliberalismo, o Quê? Trabalho apresentado no Seminário Novos Rumos do Desenvolvimento do Mundo. Rio de Janeiro, BNDES, $12-13$ de setembro.

RUCKERT, Arne. (2009), “A Decade of Poverty Reduction Strategies in Latin America: Empowering or Disciplining the Poor?". Labour, Capital and Society, vol. 42, nos 1 e 2, pp. 57-81. 
. (2010), "The Forgotten Dimension of Social Reproduction: The World Bank and the Poverty Reduction Strategy Paradigm". Review of International Political Economy, vol. 17, no 5, pp. 816-839.

STIGLITZ, Joseph. (1998), “Más Instrumentos y Metas más Amplias para el Desarrollo. Hacia el Consenso Post-Washington". Desarrollo Económico, vol. 38, no 151, pp. 13-57.

. (2000), “Distribuição, Eficiência e Voz: Elaborando a Segunda Geração de Reformas", in E. Teófilo (org.), Distribuição de Riqueza e Crescimento Econômico. Brasília, MDA/CNDRS/NEAD, pp. 29-59.

. (2000a), "O Que Eu Aprendi com a Crise Mundial". Revista de Economia Política, vol. 20, no 3, pp. 169-174.

STOLOWICZ, Beatriz. (2012), A Contracorriente de la Hegemonía Conservadora. Bogotá, Espacio Crítico.

TAYLOR, Marcus e SOEDERBERG, Susanne. (2007), "The King is Dead (Long Live the King?): From Wolfensohn to Wolfowitz at the World Bank", in D. Moore (ed.), The World Bank: Development, Poverty, Hegemony. Scottsville, University of KwaZuluNatal Press, pp. 453-477.

THIRKELL-WHITE, Ben. (2009), "Poverty Reduction in Indonesia: Why Pro-poor Growth Requires more than 'Getting Institutions Right'". Labour, Capital and Society, vol. 42, nos 1 e 2, pp. 141-166.

VESTERGAARD, Jakob e WADE, Robert H. (2013), “Protecting Power: How Western States Retain the Dominant Voice in the World Bank's Governance". World Development, vol. 46, pp. 153-164.

VILAS, Carlos M. (2000), “ ¿Más allá del ‘Consenso de Washington’? Un Enfoque desde la Política de Algunas Propuestas del Banco Mundial sobre la Reforma Institucional”. América Latina Hoy, no 26, pp. 21-39.

. (2012), Después del Neoliberalismo: Estado y Procesos Políticos en América Latina. Remedios de Escalada, Buenos Aires, UNLa.

WADE, Robert H. (1997), “Japón, el Banco Mundial y el Arte del Mantenimiento del Paradigma: El Milagro del Este Asiático en Perspectiva Política". Desarrollo Económico, vol. 37, no 147, pp. 351-387.

. (1997a), "Greening the Bank: The Struggle over the Environment, 1970-1995", in D. Kapur et al. (eds.), The World Bank: Its First Half Century - Perspectives. Washington DC, Brookings Institution Press, vol. 2, pp. 611-734.

. (2001), “Making the WDR 2000: Attacking Poverty”. World Development, vol. 29, no 8, pp. 1435-1441.

. (2001a), “Enfrentamiento en el Banco Mundial”. New Left Review, no 7, pp. 112-124.

. (2002), “US Hegemony and the World Bank: The Fight over People and Ideas”. Review of International Political Economy, vol. 9, no 2, pp. 215-243.

. (2010), "The State of the World Bank". Challenge, vol. 53, no 4, pp. 43-67.

. (2013), "The Art of Power Maintenance: How Western States Keep the Lead in Global Organizations". Challenge, vol. 56, no 1, pp. 5-39. 


\section{João Márcio Mendes Pereira}

e VENEROSO, Frank. (1998), “The Asian Crisis: The High Debt Model Versus the Wall Street-Treasury-IMF Complex". New Left Review, no 228, pp. 3-23.

WILLIAMS, David. (2008), The World Bank and Social Transformation in International Politics. London/New York, Routledge.

e YOUNG, Tom. (2007), "The World Bank and the Liberal Project", in D. Moore (ed.), The World Bank: Development, Poverty, Hegemony. Scottsville, University of KwaZulu-Natal Press, pp. 203-225.

WILLIAMSON, John. (1990), “What Washington Means by Policy Reform”, in J. Williamson (ed.), Latin American Adjustment: How Much has Happened. Washington, DC, IIE, pp. 5-20.

(1998), “Revisión del Consenso de Washington”, in L. Emmerij e J. Nuñez del Arco (orgs.), El Desarrollo Económico y Social en los Umbrales del Siglo XXI. Washington, DC, BID, pp. 51-65.

WOLFENSOHN, James. (1998), La Otra Crisis. Discurso proferido na reunião anual da Junta de Governadores do Banco Mundial. Washington, DC, 6 de outubro.

. (1999), Propuesta para un Marco Integral de Desarrollo. Discurso proferido na reunião anual do Banco Mundial. Washington, DC, 21 de janeiro.

. (2004), Segurança e Desenvolvimento no Século XXI. Discurso proferido na reunião anual do Banco Mundial e do Fundo Monetário Internacional, Washington, DC, 3 de outubro.

WOODS, Ngaire. (2006), The Globalizers: The IMF, the World Bank and their Borrowers. Ithaca/London, Cornell University Press.

ZURBRIGGEN, Cristina. (2007), “La 'Falácia Tecnocrática' y la Reforma del Estado: A 10 Años del Informe del Banco Mundial”. Nueva Sociedad, no 210, pp. 156-172. 


\section{RESUMO}

Continuidade, Ruptura ou Reciclagem? Uma Análise do Programa

Político do Banco Mundial após o Consenso de Washington

O presente artigo analisa a evolução do programa político do Banco Mundial entre os anos de 1989 e 2014, com base na documentação da própria instituição, considerada a partir da sua condição singular de emprestador, formulador e articulador de políticas e veiculador de ideias e prescrições sobre o que fazer em matéria de desenvolvimento capitalista, em clave anglo-saxônica. Argumenta-se que tal programa se reciclou, se expandiu e se diversificou, uma vez que, além da liberalização, da privatização e do ajuste macroeconômico, passou a impulsionar a reconstrução abrangente da economia, da relação sociedade-natureza, do Estado, da sociedade civil e do próprio self, em chave liberal, nos países clientes. Destaca-se a importância da incorporação do neo-institucionalismo para tal expansão e reciclagem e ressalta-se como esse processo foi concomitante ao alargamento contínuo do mandato do Banco Mundial.

Palavras-chave: Banco Mundial; neoliberalismo; neoinstitucionalismo; reforma do Estado; combate à pobreza

\section{ABSTRACT \\ Continuity, Rupture or Recycling? An Analysis of the Political Agenda of the World Bank after the Washington Consensus}

This article analyzes the evolution of the political agenda of the World Bank between the years 1989 and 2014, based on documents produced by institution itself, considered from its unique positions as a lender, formulator and articulator of policies and also as a champion of ideas and prescriptions as to what measured should be taken for capitalist development in its Anglo-Saxon definition. It is argued that this agenda was recycled, expanded and diversified to the extent that, in addition to liberalization, privatization and macroeconomic adjustment, it also became the driving force of the broad reconstruction of the economy, the relationship between society and nature, and even the self, from the liberal perspective in client countries. The importance of the incorporation of neo-institutionalism in this expansion and recycling of the agenda is highlighted. The article also points out how this process occurred in tandem with continuous enlargement of the World Bank's mandate.

Keywords: neoliberalism; neo-institutionalism; State reform; struggle against poverty 


\section{RÉSUMÉ}

Continuité, Rupture ou Recyclage? Une Analyse du Programme Politique de la Banque Mondiale après le Consensus de Washington

Cet article analyse l'évolution du programme politique de la Banque Mondiale entre 1989 et 2014 à partir des documents publiés par l'institution elle-même et sur la base de sa condition singulière de prêteur, d'élaborateur et articulateur de politiques, et de propagateur d'idées et de prescriptions d'inspiration anglo-saxonne sur ce qu'il faut faire en matière de développement capitaliste. L'argument ici proposé est que son programme s'est recyclé, étendu et diversifié. De fait, outre la libéralisation, la privatisation et les ajustements macroéconomiques, l'institution promeut aujourd'hui dans les pays clients une reconstruction de grande ampleur et en mode libéral de l'économie, des relations société-nature, de l'État, de la société civile et d'elle-même. On soulignera l'importance de l'incorporation du néo-institutionnalisme dans cette expansion et ce recyclage, ainsi que la concomitance entre ce processus et l'élargissement continu du mandant de la Banque Mondiale.

Mots-clés: Banque Mondiale; néolibéralisme; néo-institutionnalisme; réforme de l'État; lutte contre la pauvreté

\section{RESUMEN}

Continuidad, Ruptura o Reciclaje? Un Análisis del Programa Politico del Banco Mundial tras el Consenso de Washington

Este artículo analiza la evolución del programa político del Banco Mundial entre los años de 1989 y 2014, utilizando como fuente la documentación de la propia institución, considerada a partir de su singular condición de prestatario, formulador y articulador de políticas y difusor de ideas y prescripciones sobre qué hacer en materia de desarrollo capitalista, en clave anglosajona. Se argumenta que tal programa se recicló, se expandió y se diversificó, una vez que, además de la liberalización, de la privatización y del ajuste macroeconómico, pasó a impulsar la reconstrucción de la economía, de la relación sociedadnaturaleza, del Estado, de la sociedad civil y del propio self, en clave liberal, en los países clientes. Subrayase, finalmente, la importancia del neoinstitucionalismo para tal expansión y reciclaje y se examina cómo este proceso se produjo de forma paralela al ensanchamiento continuo del mandato del Banco Mundial.

Palabras clave: Banco Mundial; neoliberalismo; neoinstitucionalismo; reforma del Estado; combate a la pobreza 